\title{
Where geology meets engineering in hydrothermally altered environments: considering veins in geotechnical engineering
}

\author{
JJ Day Queen's University, Canada \\ MD Clark Queen's University, Canada \\ GA Rudderham Queen's University, Canada
}

\begin{abstract}
The mechanical properties of intact rock and fractures are key components that control rockmass behaviour in homogeneous rockmasses, which are the basis of many field characterization protocols, laboratory measurement, and numerical modelling approaches in geotechnical engineering. While effective in many cases of surface and underground excavations, these approaches are no longer adequate for particularly deep excavations in heterogeneous rockmasses, such as those with hydrothermal veins, stockwork, or other types of intrablock structures. Accounting for intrablock structures and other rockmass heterogeneity in rock engineering design has become critical for the safety and economic success of giant open pit mines, block caving operations, and other deep excavations. To do so, numerical modelling tools need to be integrated with improved characterization of heterogeneous rockmasses with all types of rockmass structures. In this work, the authors discuss rockmass characterization methodologies to address this challenge, including in field and laboratory settings, for application to numerical geotechnical design. Techniques to assess rock and vein mineralogies are discussed and examples illustrate the variety of mineralogies in porphyry and skarn ore deposits. Geotechnical field assessments of veined rockmasses in stress environments where shear-based failure and brittle spalling failure occur are presented. Geomechanical laboratory testing of veined rocks is discussed and a case study of unconfined compressive stress (UCS) tests on rocks from the Canadian Legacy skarn deposit is presented, where the interpretations of UCS test results are explained using mineralogical analyses. Geological interpretations of these heterogeneous rocks are an important part of understanding their geomechanical behaviours and extrapolating to predict rockmass behaviours at the excavation scale both empirically and numerically.
\end{abstract}

\section{Introduction}

Predicting the geomechanical behaviour of rockmasses is critical to the economic success and safety of rock engineering projects such as Andean base tunnels, deep open pit mines, and large underground sublevel and block cave mining operations. Intact rock and fracture components of rockmasses are the basis of many protocols for field characterization, laboratory measurements, and numerical modelling of homogeneous rockmasses for geotechnical engineering. While effective in many cases of surface and underground excavations, homogeneous rockmass approaches are no longer adequate for particularly deep excavations in heterogeneous or complex rockmasses, such as those containing hydrothermal 
veins, stockwork, or other types of intrablock structures. From a geomechanical perspective, intrablock structures are defined as meso-scale structures within fracture-bounded blocks of otherwise intact rock. Intrablock structures influence rockmass shear and tensile strength as well as deformability (stiffness), and their mechanical behaviour depends on thickness, persistence, orientation, mineralization, and the relative mineralogy and associated mechanical properties of the surrounding wall rocks (Day et al. 2019; Clark 2020). Porphyry and related skarn ore deposits, which are commonly extracted using open pit or cave mass mining methods, contain pervasive and variable stockwork veining throughout. Accounting for such rockmass heterogeneities in rock engineering for excavation design should be done using an integrative approach at the stages of site investigation and field observations, geomechanical laboratory testing, and excavation scale numerical modelling. This includes forward thinking from preliminary field data collection with a focus toward determining appropriate input properties in geomechanics numerical models, as well as integration of insights from geological data and models into geotechnical applications.

Inaccurate rockmass characterization that leads to inadequate ground support has been documented to increase worker safety risk related to ground failure. For example, from 2000-2014, 45 fatal injuries occurred in Ontario, Canada, of which 8 (18\%) were caused by fall of rock (MOL 2015). While the number of injuries associated with rock falls has decreased since the mid-1900s with improvements to excavation design and ground support, significant work remains to achieve zero-harm workplaces. In addition to infrastructure ground support, intrablock structures have geomechanical significance in other aspects of large-scale mining, including fragmentation and caving control, blasting and crushing of rock blocks, and ore processing at the mill.

To achieve successful geotechnical designs of excavations, numerical modelling tools need to be integrated with improved characterization of complex rockmasses with all types of rockmass structures. There is a rapidly growing body of literature on incorporating intrablock structures into numerical models at the laboratory sample scale (e.g. Shang 2020; Bahrani et al. 2018; Turichshev \& Hadjigeorgiou 2017; Vallejos et al. 2016), rock block scale (e.g. Stavrou et al. 2019), excavation scale (e.g. Day et al. 2015a), and caving scale (e.g. Garza-Cruz \& Pierce 2016). This paper focuses on the site investigation process in the field and laboratory of gathering and measuring geomechanical properties and other information needed for inputs to numerical models of heterogeneous rocks and rockmasses. An emphasis is made on the importance of understanding the geological setting and mineralogical composition of rocks and intrablock structures.

The variety of vein mineralogies in hydrothermal ore deposits and geological techniques to characterize rock and vein mineralogies are discussed. Geotechnical field assessments of veined rockmasses in stress environments where both shear and brittle failure occur are presented. Geomechanical laboratory testing of veined rocks is discussed and a case study of unconfined compressive stress (UCS) tests on rocks from the Canadian Legacy skarn deposit is presented, where the interpretations of UCS test results are explained using mineralogical analyses.

\section{Geological observations of hydrothermal veins}

Hydrothermal veins in ore deposits are composed of an impressive variety of mineralogies, orientations, associations with various lithologies, and timing of emplacement throughout the geological history of the formation of a deposit. Examples of deposits that contain veins and their mineralogies are listed in Table 1 , and photos of several vein mineralogies are shown in Figure 1. 

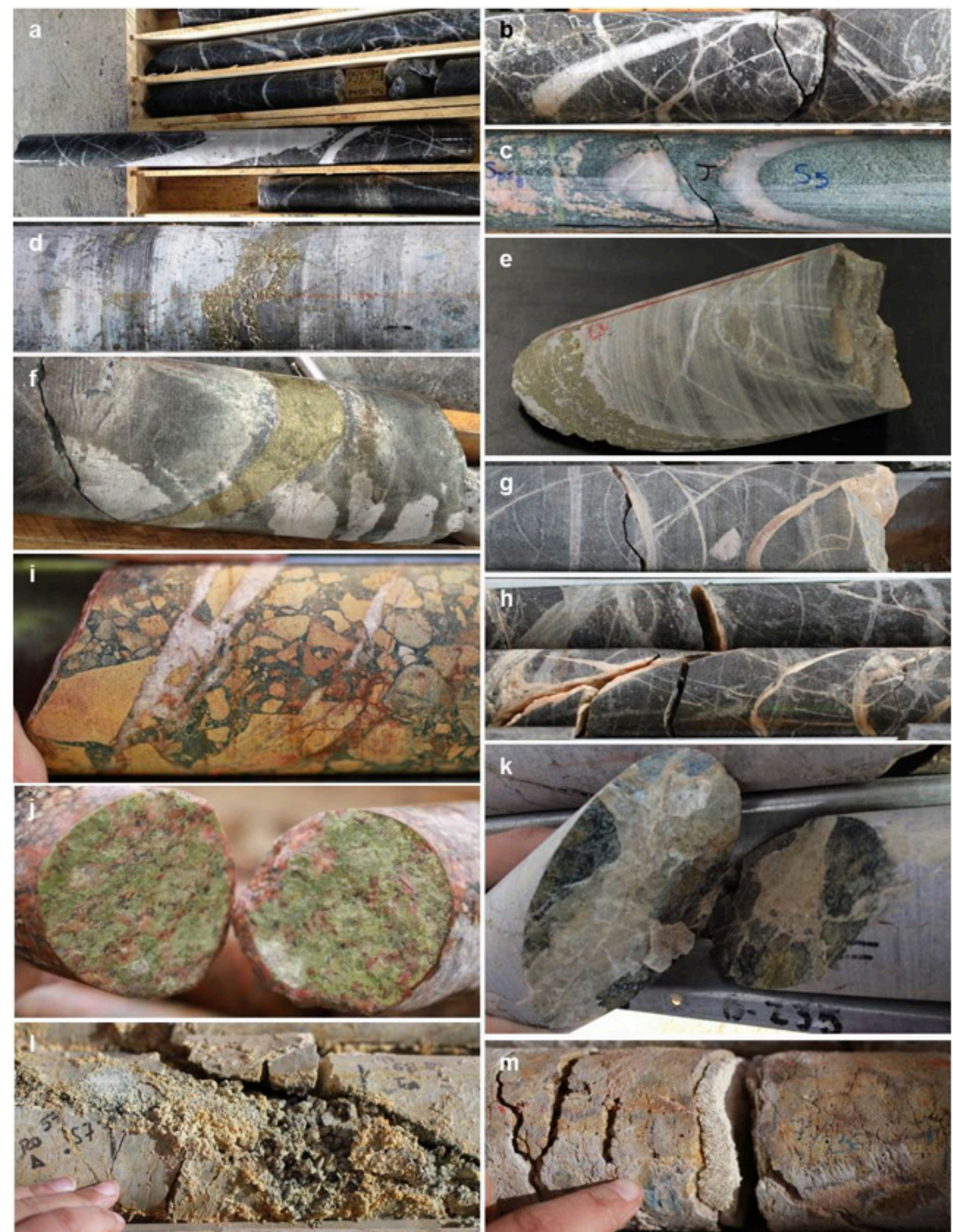

Figure 1 Examples of hydrothermal veins in drill core from Chile and Canada with various contact qualities; a-c quartz; d-f pyrite, chalcopyrite \pm quartz; g-i gypsum; j epidote; $k$ calcite; l-m swelling clay that expanded with water application during core logging (Day et al. 2019) 
Table 1 Examples of large ore deposits, their major lithologies and hydrothermal vein mineralogies

\begin{tabular}{|c|c|c|c|c|c|}
\hline $\begin{array}{l}\text { Deposit } \\
\text { Name }\end{array}$ & Location & Deposit Type & Major Lithologies & Vein Mineralogies & References \\
\hline El Teniente & Chile & Cu-Mo Porphyry & $\begin{array}{c}\text { Basalt-andesite mafic } \\
\text { complex, dacite, diorite, } \\
\text { breccia, tonalite }\end{array}$ & $\begin{array}{c}\text { Qtz, Bt, Ccp, Bo, Py, } \\
\text { Mo, Ms, Anh, Chl, Fsp, } \\
\text { Tour }\end{array}$ & $\begin{array}{l}\text { Skewes et al. } \\
2002\end{array}$ \\
\hline Chuquicamata & Chile & Cu-Mo Porphyry & $\begin{array}{l}\text { Hornblende-biotite } \\
\text { granodiorite }\end{array}$ & $\begin{array}{c}\text { Hypogene: Py, Ccp, Bo, } \\
\text { Cv, Dg,Sph; Supergene: } \\
\text { Anh,Gp }\end{array}$ & $\begin{array}{l}\text { Véliz et al. } \\
2017\end{array}$ \\
\hline Rosario & Chile & Cu-Mo Porphyry & $\begin{array}{l}\text { Fsp-Qtz-Bt phyric } \\
\text { Monzonite }\end{array}$ & $\begin{array}{l}\text { Qtz, Bt, KFs, Ccp, Bn, } \\
\text { Bt, Mo, Py, Ab, Mag }\end{array}$ & $\begin{array}{l}\text { Masterman et } \\
\text { al. } 2004\end{array}$ \\
\hline Mines Gaspé & Canada & $\begin{array}{l}\text { Cu-Mo Porphyry } \\
+ \text { Skarn }\end{array}$ & $\begin{array}{l}\text { Rhyodacite, meta- } \\
\text { limestone skarn }\end{array}$ & $\begin{array}{l}\text { Qtz, Fsp, Px, Grt, Ccp, } \\
\text { Po, Fl, Anh, Kfs, Mag, } \\
\text { Py, Mo, Cal, Sph, Ms, } \\
\text { Chl, Sch }\end{array}$ & Allcock 1982 \\
\hline Grasberg & Indonesia & $\begin{array}{l}\text { Cu-Au Porphyry } \\
+ \text { Skarn }\end{array}$ & $\begin{array}{l}\text { Grasberg lgneous } \\
\text { Complex, Diorite- } \\
\text { monzodiorite }\end{array}$ & $\begin{array}{c}\text { Qtz, Mag, Ccp-Au, Bn, } \\
\text { Dg, Cv, Fsp, Anh, Bt }\end{array}$ & $\begin{array}{l}\text { MacDonald \& } \\
\text { Arnold } 1994\end{array}$ \\
\hline Oyu Tolgoi & Mongolia & Cu-Au Porphyry & $\begin{array}{l}\text { Qtz monzodiorite, } \\
\text { Aug basalt, dacitic } \\
\text { pyroclastic rocks }\end{array}$ & $\begin{array}{c}\text { Qtz, KFs, Bt-Mag, Ccp, } \\
\text { Bo, Au, Py, Cv, Cc, Ms, } \\
\text { Chl, Mo, Ep }\end{array}$ & Porter 2016 \\
\hline
\end{tabular}

\section{Geological techniques to characterize veined rocks}

Geological characterization of veined rocks in an ore deposit primarily involves mineralogical and geochemical analyses. It is also important to understand the geological setting and history of the deposit to provide context to the mineralogical test results. There are several options available for mineralogical analyses, including hand sample mineral identification using field tools (e.g. hand lens, knife, streak plate, magnet, and hydrochloric acid), and laboratory techniques at the microscopic scale. Laboratory techniques include petrographic analysis of thin sections (refracted and reflected light microscopy), bulk powdered or spatially mapped X-Ray Diffraction (XRD), scanning electron microscopy (SEM) coupled with back-scatter electron (BSE) detector and Energy Dispersive Spectrometry (EDS) analysis for mineral liberation analysis (MLA), spatially mapped micro-X-Ray-Fluorescence ( $\mu$-XRF), and spot averaged portable $X$-Ray Fluorescence (pXRF).

\subsection{Petrographic analysis of thin sections}

Petrographic analysis of thin sections is a very powerful tool that enables spatial evaluation of grain mineralogy, modal mineralogy, grain size, insight into deformation history, and quality of contacts between grains (e.g. at boundary between vein and wall rock materials). A limitation of its effectiveness is magnification power where it becomes difficult to evaluate very fine-grained mineral assemblages.

\subsection{Laboratory measurement of crystallographic mineralogy}

XRD provides crystallographic mineralogy, commonly for bulk powdered samples that do not provide spatial information; however, newer XRD technologies can test thin sections or offcuts to provide spatial mineralogy information. The accuracy of XRD results depends on the user's understanding of the geological setting of the sample and general sense of what minerals may be expected in a sample, 
based on desktop and/or field studies of the source location and petrographic analysis of thin sections. Mineralogy from XRD results is identified by best fits to databases of previously tested minerals with known peak signatures (e.g. ICDD 2020).

\subsection{Nanoscale crack observations and measurements of elemental composition}

SEM provides microscopic to nanoscopic visual information of grain texture and crack observations in thin section. Coupled with EDS and MLA analysis, spatially mapped elemental compositions of the mineral grains can be determined. The elemental signatures of analysed points (which may contain more than one mineral) are user defined and based on understanding the elemental composition of minerals. Again, it is important to understand the geological setting and compare results to petrographic analysis (and even XRD) for MLA analysis to be an effective and accurate tool. MLA analysis using SEM is similar to that of $\mu-X R F$, which also provides a spatial map of elemental compositions on a sample surface. Furthermore, $\mu$-XRF provides details about trace element concentration and distribution, which are useful for developing geochemical profiles of tested samples. However, like MLA, the accuracy of $\mu$-XRF results depends on understanding the source geology and comparing the results against petrographic analysis and XRD.

Portable XRF ( $\mathrm{pXRF}$ ) has become a common exploration tool in the mining industry, where spot scans at regular intervals along drill core provide the elemental composition of a $2 \mathrm{~cm}$ diameter area. Further analytical studies using laboratory techniques like those discussed above are typically used to confirm and/or calibrate the pXRF results. pXRF can be very helpful for analysing lithostratigraphic sequences of ore deposits and developing models of ore deposit formations. This tool is attractive to users because of its relative ease of analysis, rapid analysis time (with minimal sample preparation requirements), and relatively low cost.

\subsection{Case study: mineralogy of Legacy skarn deposit}

Thin sections and mineral identifications (based on hand sample, petrographic, XRD, and $\mu$-XRF analyses) of three units from the Legacy skarn deposit, including red granodiorite, calcareous mudstone, and garnetpyroxene skarn, are shown in Figure 2. The thin section images show matrix (i.e. wall rock or ground mass) and vein components of the rocks in both plane polarized light (PPL) and cross-polarized light (XPL). Photos of the thin section offcuts are shown at centre in true colours. Geomechanical properties and interpretations of the results based on mineralogy are discussed in Section 5. 

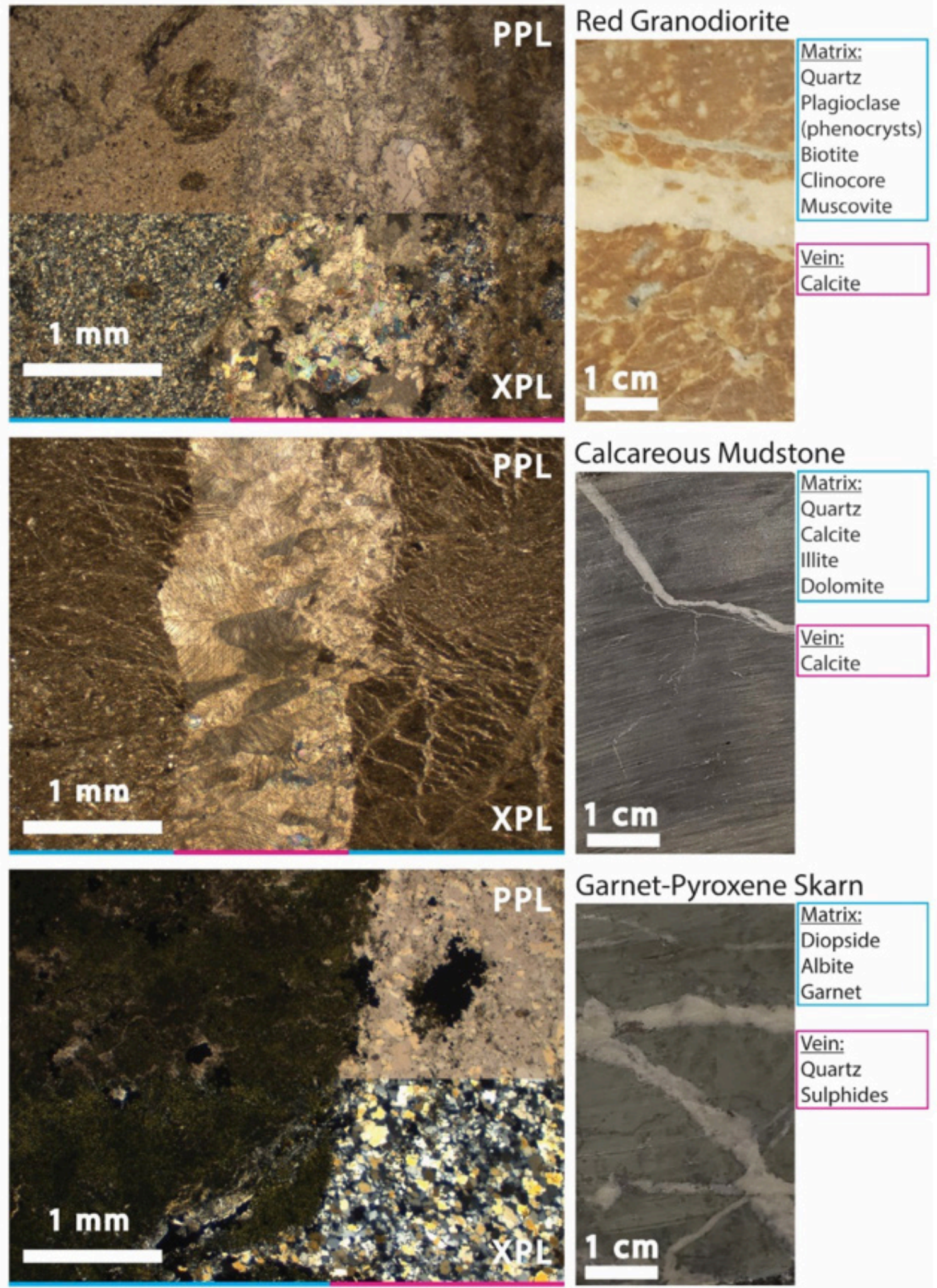

Figure 2 Mineralogy of (top) red granodiorite, (middle) calcareous mudstone, and (bottom) Grt-Px skarn units from Legacy Skarn deposit with thin sections showing matrix and vein components of each (data from Clark 2020)

\section{$4 \quad$ Geotechnical field assessment of veined rockmasses}

Many conventional geotechnical site investigation programs are designed to collect data through the lens of empirical classification parameters; however, this does not satisfy all the input parameters needed for a sophisticated numerical design approach. Bewick \& Kaiser (2016) show that application of empirical classification systems for conventional rockmasses to veined rockmasses may lead to unreliable ratings, 
and provide practical guidelines on drill core logging of veined rocks to consider potential damage from blasting and transportation to drill core that may induce fractures between in situ conditions, borehole collar, and the core shed. Particularly for cave mining, the collection and use of high-quality geotechnical data and accurate prediction of fragmentation have been highlighted as two significant challenges in industry (Chitombo 2010). Improvements to numerical geotechnical design must begin with effective site investigation and field data collection.

\subsection{Field evaluations for model input parameters}

The Geological Strength Index (GSI) (Hoek et al. 2013) and the Generalized Hoek-Brown strength criterion (Hoek et al. 2002) continue to be effective methods to translate field observations of conventional rockmasses (i.e. rockmasses comprised of intact rock and fractures) into numerical modelling input properties for continuum numerical models to simulate shear-driven rockmass yield in lower stress environments. To characterize complex rockmasses at the field rockmass or excavation scale, the Composite GSI methodology and revised GSI chart that includes intrablock structures by Day et al. (2019) can be used to evaluate multiple suites of rockmass structures (any combination of interblock or intrablock structures) (CGSI chart shown here in Figure 3).

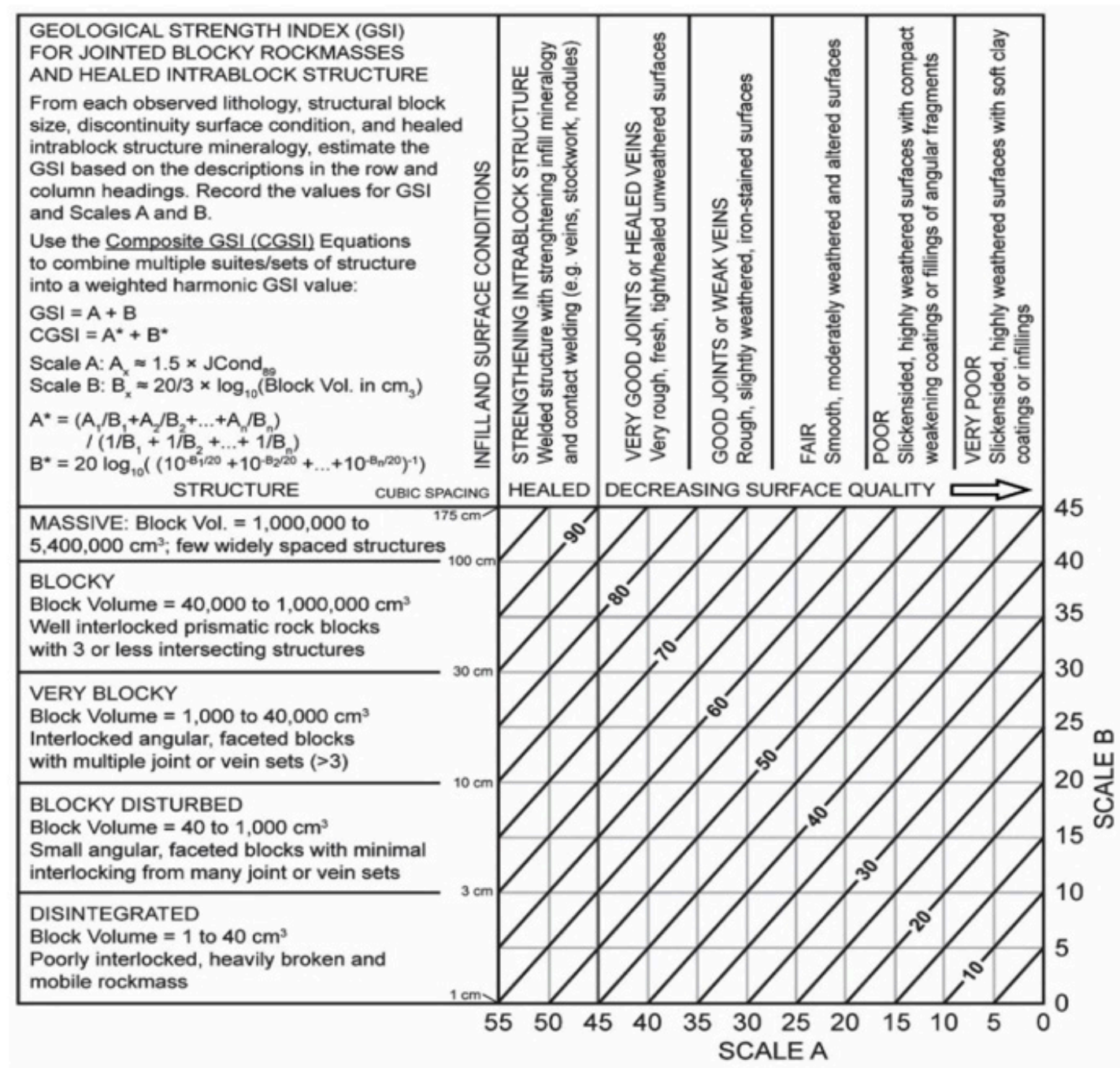

Figure 3 Composite GSI equations and revised GSI chart with intrablock structures (Day et al. 2019)

By adapting GSI to complex rockmasses, the system retains the benefits of determining parameters for the Hoek-Brown strength criterion that can be input directly into numerical models that simulate sheardriven rockmass yield. Nevertheless, GSI and the Hoek-Brown strength criterion do not capture brittle rockmass behaviour. In this case, brittle rock failure criteria such as the Damage Initiation Spalling Limit (DISL; Diederichs 2003, 2007) and Cohesion-Weakening Friction-Strengthening (CWFS; Hajiabdolmajid et 
al. 2002) are appropriate for numerical modelling. Input parameters for these criteria include the brittle damage thresholds, crack initiation $(\mathrm{Cl})$ and crack damage (CD), which are measured from laboratory test data of intact rocks.

\subsection{Brittle overbreak prediction at excavation scale}

For field assessment of veined rockmasses at the excavation scale in high in situ and deviatoric stresses, empirical brittle overbreak predictions provide preliminary predictions of spalling-related damage around excavations, which can provide important information for developing appropriate ground support and construction practices. Using case studies of excavations in various types of moderately jointed to massive conventional rockmasses, Martin et al. (1999) found a linear relationship between depth of brittle overbreak normalized to excavation radius and maximum tangential ground stress normalized to uniaxial compressive strength (or crack initiation; Diederichs 2010).

Day (2019) showed that heterogeneous rockmasses in the New Mine Level at the El Teniente porphyry mine in Chile, including the stockwork mafic complex, dacite porphyry, anhydrite breccia, and brecciated contact zone between the stockwork mafic complex and dacite porphyry units, exhibit a poor correlation to the linear empirical function of brittle overbreak depth defined by Martin et al. (1999). A more appropriate nonlinear and concave function form, which was successfully used by Perras and Diederichs (2016) to evaluate depth of excavation damage zones, was proposed by Day (2019) to improve predictions of depth of brittle overbreak in these heterogeneous rockmasses, as shown in Figure 4.

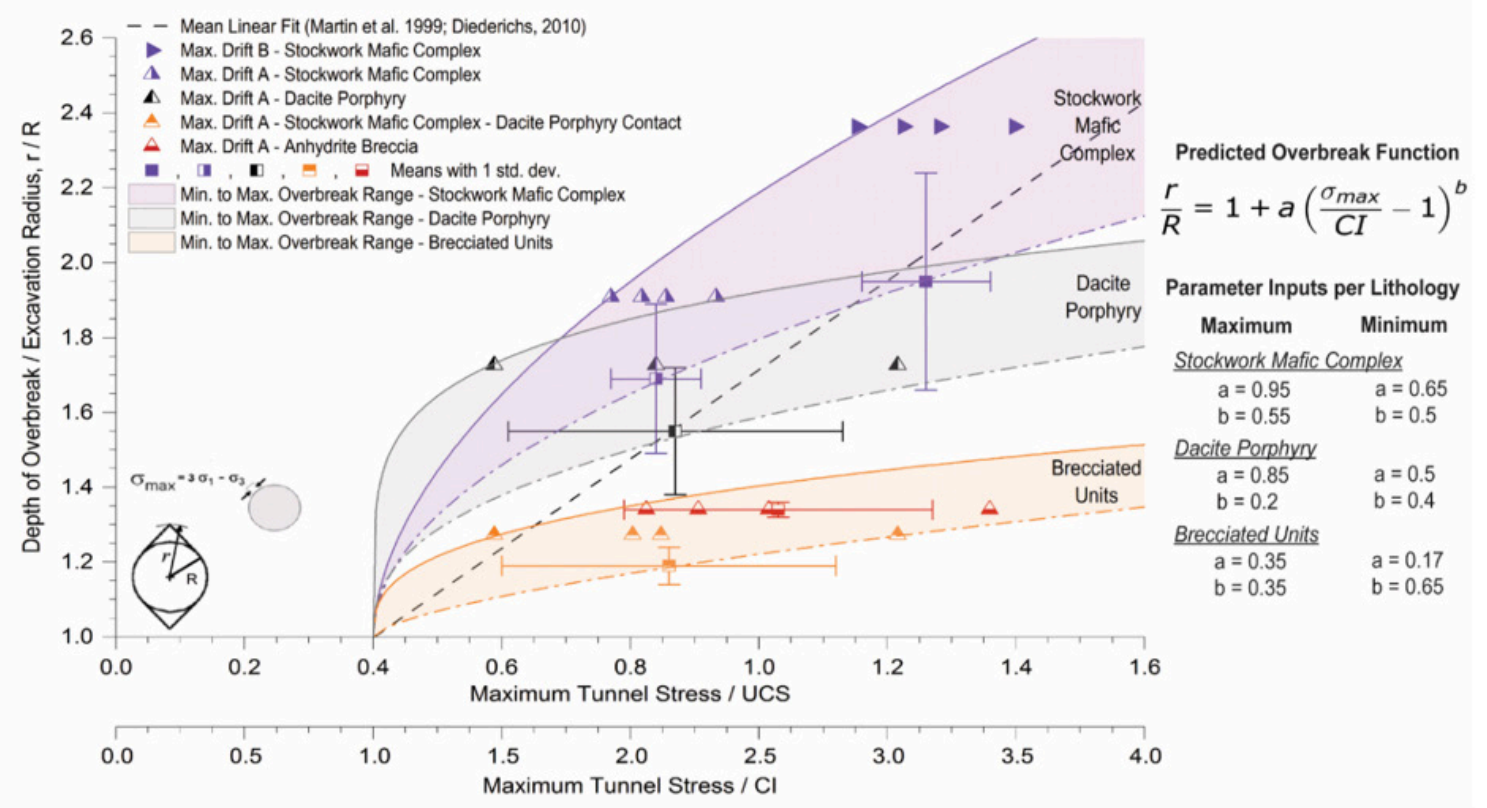

Figure 4 Brittle overbreak prediction functions of three types of heterogeneous rockmasses at El Teniente New Mine Level based on excavation overbreak observations and laboratory test results (modified after Day 2019)

The dacite porphyry unit, which contains few stockwork veins, most closely resembles the expected homogeneous prediction of brittle overbreak. The stockwork mafic complex exhibits overbreak that dominantly exceeds the homogeneous prediction because the planar, pervasive quartz veins act as crack attractors and promote crack propagation after initiation and immediate strength loss. The anhydrite breccia unit and brecciated contact zone between the stockwork mafic complex and dacite porphyry units contain large clasts of contrasting mineralogy (and consequently contrasting geomechanical properties) that act as crack arresters, resulting in brittle overbreak that is largely less than in homogeneous rockmasses. Photograph examples and conceptual models of brittle overbreak behaviours in these units are illustrated in Figure 5. 


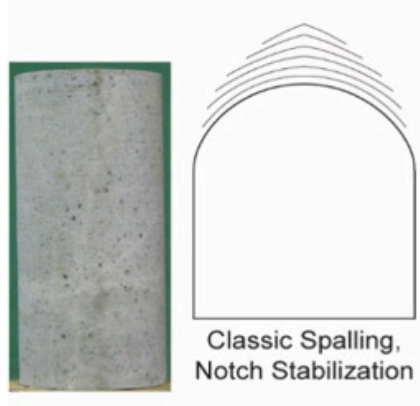

Dacite Unit

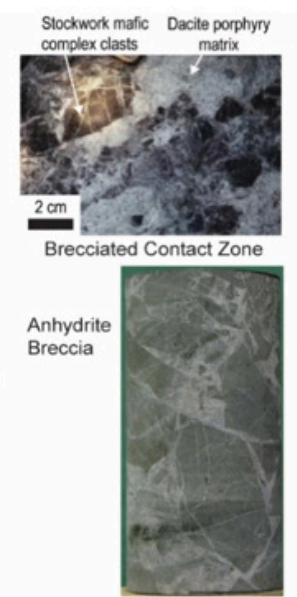

Breccia Units

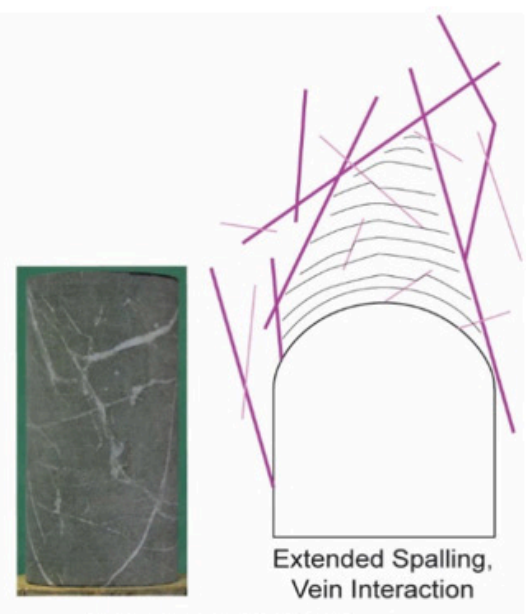

Stockwork Unit

Figure 5 Examples of UCS test samples (101 mm diameter) of three lithologies at El Teniente, photo of the brecciated contact zone, and conceptual models of brittle overbreak behaviours in each unit (modified after Day 2019)

\subsection{Data collection for numerical geotechnical design}

For advanced numerical geotechnical design using discontinuum models where rockmass structures are modelled discretely, additional rockmass properties must be collected during field and laboratory rockmass characterizations: geometry of structures and mechanical properties (Table 2). Geometric properties are collected at outcrops, excavation faces (e.g. Brzovic \& Molina 2017), line mapping (e.g. Brzovic \& Villaescusa 2007), from drill core (e.g. Day et al. 2015b), and laboratory test samples (e.g. Clark 2020), while mechanical properties can be estimated in the field and from drill core or measured in the laboratory with various geomechanical tests. Measuring networks of intrablock structures using intact rock tests and capturing their influence through intact rock mechanical properties are briefly discussed in Section 5.

Table 2 Data needed for discontinuum numerical models of individual discrete rockmass structures

\begin{tabular}{|c|c|c|c|c|c|}
\hline $\begin{array}{c}\text { Geometric } \\
\text { parameters }\end{array}$ & $\begin{array}{c}\text { Interblock } \\
\text { structures }\end{array}$ & $\begin{array}{c}\text { Intrablock } \\
\text { structures }\end{array}$ & $\begin{array}{c}\text { Mechanical } \\
\text { parameters }\end{array}$ & $\begin{array}{c}\text { Interblock } \\
\text { structures }\end{array}$ & $\begin{array}{c}\text { Intrablock } \\
\text { structures }\end{array}$ \\
\hline Orientation & Yes & Yes & Normal stiffness & Yes & Yes \\
\hline Spacing & Yes & Yes & Shear stiffness & Yes & Yes \\
\hline Persistence & Yes & Yes & Shear strength & Yes & Yes \\
\hline Thickness & No & Yes & Tensile strength & No (zero) & Yes \\
\hline & & & Dilation & Yes & Yes \\
\hline
\end{tabular}

Field methods to estimate mechanical properties of fractures and other interblock structures have become common in practice. Some of these include friction angle, a component of shear strength, which can be estimated using the relationship between Barton's joint roughness $\left(J_{r}\right)$ and joint alteration $\left(J_{a}\right)$ parameters, where $\omega=\tan ^{-1}\left(J_{\mathrm{r}} / J_{\mathrm{a}}\right)$ (Barton et al. 1974). Many of the Barton-Bandis shear strength criterion parameters are based on matching field observations to standard charts and using a Schmidt Hammer to measure rebound stiffness (and make correlations to fracture surface strength) (Barton \& Choubey 1977). However, when considering veins and other intrablock structures individually, field characterization using the Barton-Bandis criterion is not suitable since the criterion does not allow for nonzero cohesion or tensile strength. At this time, laboratory direct shear testing or triaxial testing of intrablock structures is needed to determine their mechanical properties for inputs to discrete numerical models. This is a relatively new area of research (Bustos et al. 2019; Day et al. 2017; de los Santos \& Brzovic 2013; Jacobsson et al. 2012; 
de los Santos Valderrama 2011) driven by deeper and more complex geotechnical and mining projects that depend on understanding the behaviour of these structures in high stress conditions (e.g. Murphy et al. 2016; Wagner 2019). Developing useful field methods to estimate mechanical properties of individual intrablock structures (e.g. during excavation face mapping and/or drill core logging) is currently an open question.

\section{$5 \quad$ Geomechanical laboratory testing of intact veined rocks}

Testing individual veins using direct shear or axisymmetric triaxial laboratory testing can be challenging due to limited sample availability from drill core where single veins are spatially isolated from other intersecting structures, and appropriately oriented with respect to the core axis, among other factors. An alternative solution to laboratory measurement of intrablock structures is to target these features in intact laboratory tests, including UCS, axisymmetric triaxial, and tensile tests. In these cases, it is possible to test networks of veins that intersect and overlap within a sample and capture the relative influence of veins versus matrix components, and consequent variability of geomechanical properties, through a suite of several tests. From these intact rock tests, stiffness, brittle damage thresholds, and strength can be measured and applied to constitutive models such as the Generalized Hoek-Brown shear (Hoek et al. 2002) or Damage Initiation Spalling Limit brittle (Diederichs 2003; 2007) strength criteria for use in numerical models. Bewick et al. (2019) recently proposed an approach to estimate a rockmass strength envelope using UCS and triaxial test data without the Hoek-Brown criterion.

Several studies have explored effects of intrablock structures on laboratory tests, including UCS (Bewick et al. 2019; Bewick et al. 2015), axisymmetric triaxial (Turichshev \& Hadjigeorgiou 2016; de los Santos \& Brzovic 2013), and direct tensile (Everall \& Sanislav 2018; Shang et al. 2016; Jacobsson et al. 2012). These results focus on conventional parameters for deformation and strength (peak and residual) and in some cases discuss influences of vein geometry on geomechanical properties, but provide limited interpretations regarding influences of mineralogy and alteration and tend to view intrablock structures as "defects" that only weaken the strength of rocks. The concept that intrablock structures are always weakening features is rooted in MRMR concepts by Laubscher \& Jakubec (2000). The Legacy skarn case study in Section 5.1 shows examples where veins strengthen UCS test samples.

Ghazvinian (2015) highlights the importance of high-quality and consistent laboratory protocols for intact rock with variable results from homogeneous rocks tested at several laboratories, which emphasizes the need for rigorous evaluation and implementation of high testing standards for heterogeneous and anisotropic rocks. It is important to select and test samples with varying amounts of intact mineral grain matrix and intrablock structures (at various orientations) to define the full range of stiffness and strength variability. This intact test data from UCS, triaxial, and tensile tests of complex rocks can then be sorted by failure mode (through the intact rock matrix versus structural failure through veins) and generate distinct failure envelopes using appropriate failure criteria.

\subsection{Case study: UCS tests on Legacy skarn deposit}

The case study of UCS tests on rocks from the Legacy Cu-Ag skarn deposit in New Brunswick, Canada shown here highlights examples where: calcite vein mineralogy either weakens or strengthens a rock depending on wall rock lithology (granodiorite vs. mudstone; Figures 6 \& 7); large vein density impedes failure through critically oriented, weak foliations (bedding) (mudstone; Figures 6 \& 7); and quartz veins strengthen or weaken a rock depending on orientation and vein density (skarn; Figures 6 \& 7). A summary of UCS test results for matrix samples in each lithology is listed in Table 3, and test results of veined rock samples in Figure 7 are normalized to this data. Detailed analyses of stiffness, crack initiation, crack damage, and peak strength are presented by Clark (2020). 

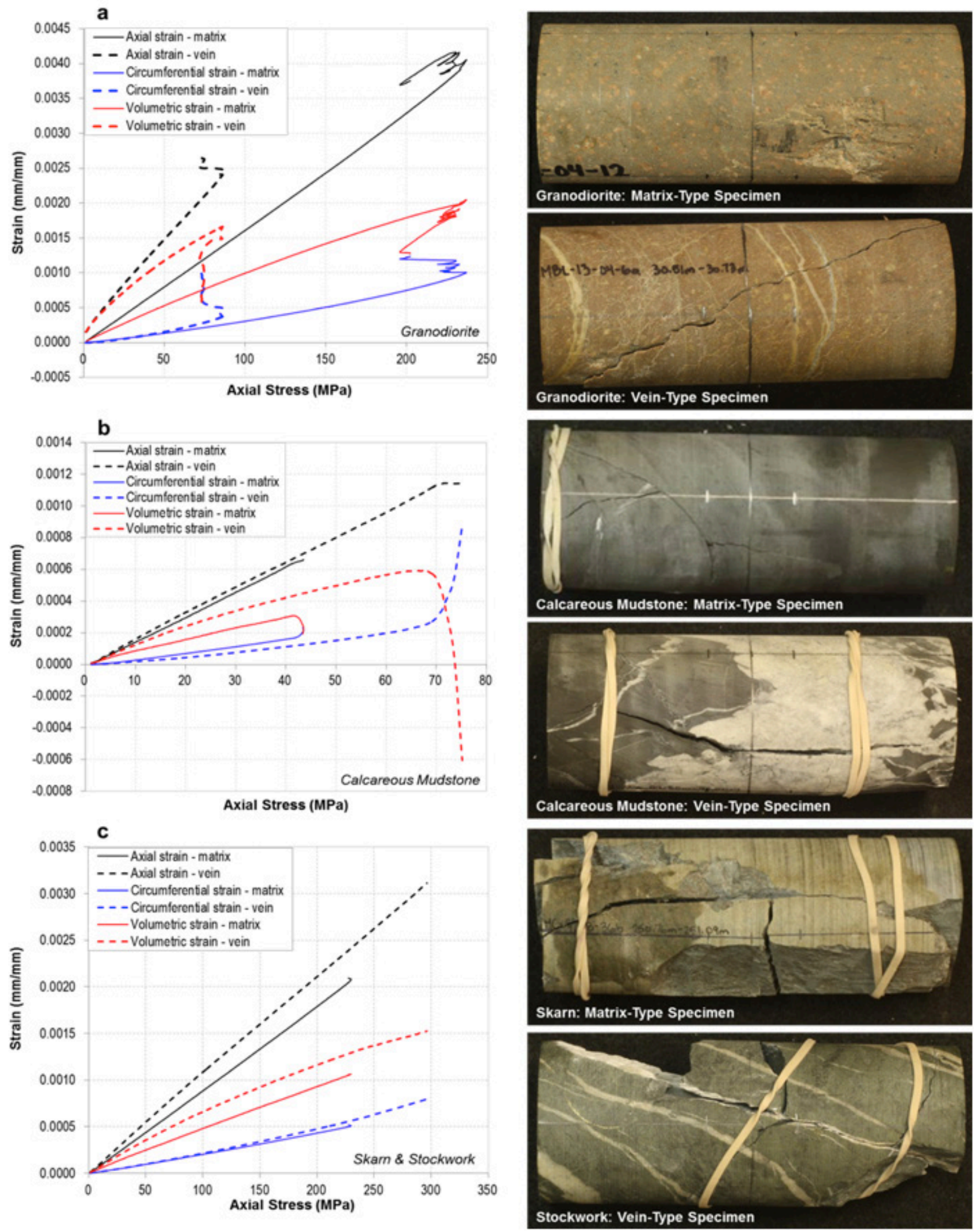

Figure 6 UCS test results for matrix and vein type samples for each of (a) red granodiorite, (b) calcareous mudstone, and (c) Gt-Px skarn stockwork units from the Legacy skarn deposit, specifically showing stress-strain extensometer measurements and photographs of the corresponding samples after testing (data from Clark 2020) 
Table 3 Summary of UCS tests on matrix-only samples from Legacy skarn deposit (from Clark 2020)

\begin{tabular}{|c|c|c|c|}
\hline Lithological unit & $\begin{array}{c}\text { No. of } \\
\text { Tests }\end{array}$ & $\begin{array}{c}\text { Average matrix sample } \\
\text { Young's Modulus (MPa) }\end{array}$ & $\begin{array}{c}\text { Average matrix sample } \\
\text { Peak Strength, } \sigma_{\mathbf{c}}(\mathbf{M P a})\end{array}$ \\
\hline Calcareous Mudstone & 6 & 61,700 & 32 \\
\hline Grt-Px Skarn & 5 & 118,000 & 258 \\
\hline Beige Granodiorite & 6 & 34,400 & 126 \\
\hline Red Granodiorite & 6 & 57,800 & 244 \\
\hline Black Granodiorite & 6 & 63,900 & 240 \\
\hline
\end{tabular}
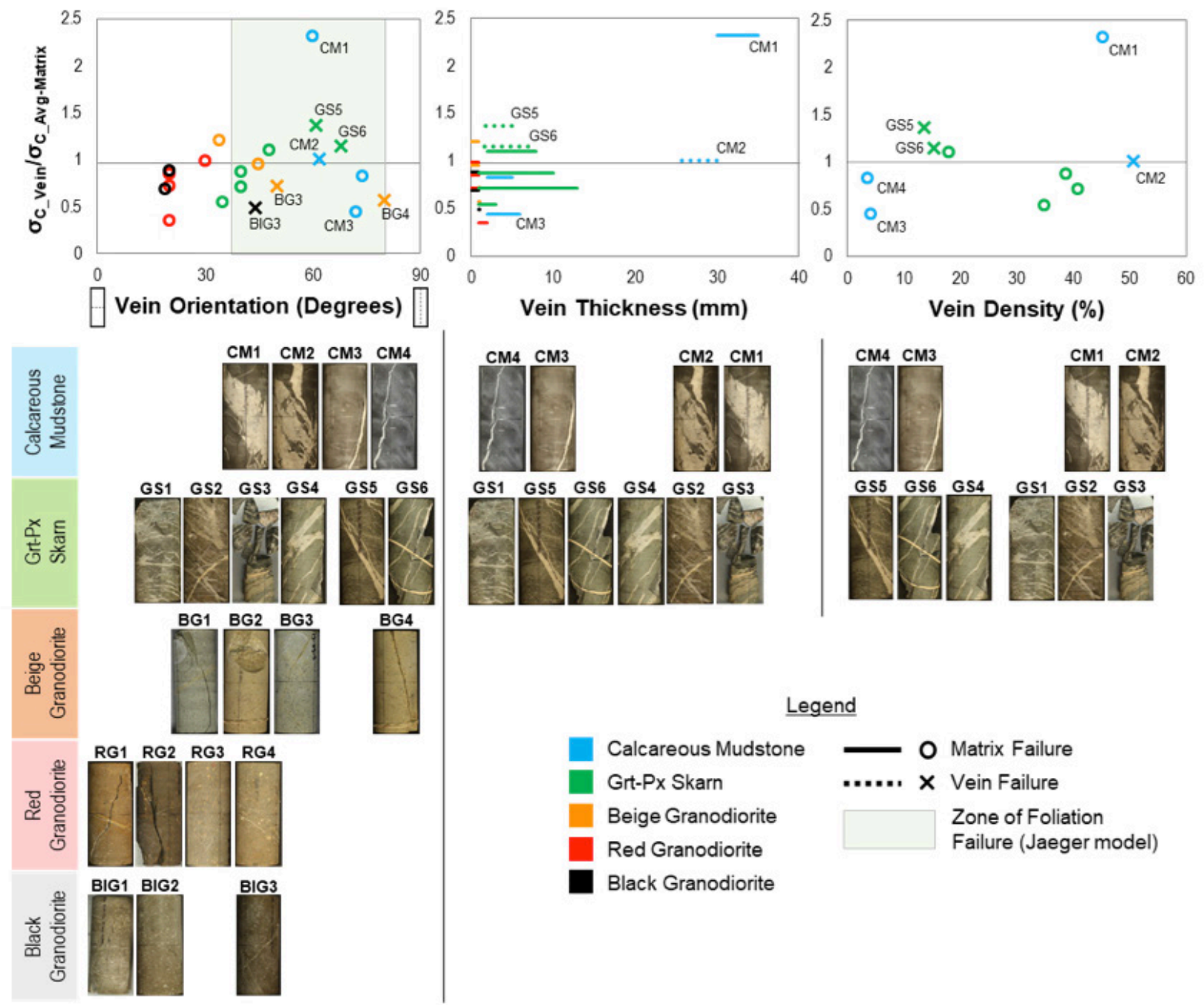

Legend

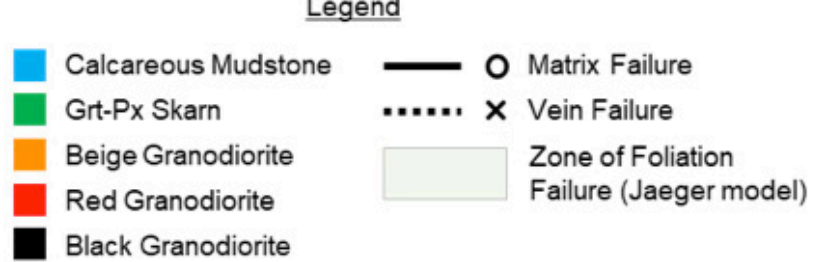

Figure 7 Comparing peak strength to vein orientation, thickness, and density from UCS tests of veined rocks from the Legacy skarn deposit; photos of each tested veined sample are sorted by lithology and arranged in order of each vein geometrical parameter; granodiorites excluded from vein thickness and density plots because maximum vein thickness in these units is limited to $1 \mathrm{~mm}$ (data from Clark 2020) 


\section{Conclusions}

It is now well known in cave mining geomechanics that veins and other intrablock structures affect rockmass strength and behaviour in large excavations and in high in situ stress environments. Researchers in academia and in mining companies are actively developing methodologies and approaches to incorporate intrablock structures into site investigation, laboratory testing, and numerical modelling. Work by the authors demonstrates the importance of understanding the mineralogy and geology of intact rocks (matrix) and intrablock structures in order to interpret geomechanical behaviours. There are a variety of geological tools to determine mineralogy, and more than one tool is usually needed. In the authors' experience, the more useful tools to determine mineralogy are hand sample field techniques, petrographic analysis of thin sections, and X-Ray Diffraction. In practice, communication between geotechnical/rock/ mining engineers and geologists is recommended to integrate geological and geomechanical models of the orebody and surrounding rockmasses for improved excavation design, mine planning, ground control, and cave fragmentation assessments.

For field assessment of geomechanical rockmass properties, the Composite Geological Strength Index (CGSI) equations by Day et al. (2019) enable suites of rockmass structures to be considered individually, and the accompanying revised chart has been developed to account for intrablock structures in rockmass characterization using CGSI, and subsequently include these structures in continuum numerical models of excavations in shear-based stress environments.

Observations of brittle overbreak in the New Mine Level at El Teniente mine in Chile led Day (2019) to develop new nonlinear empirical predictions of overbreak depth around excavations in three types of heterogeneous rockmasses, including the stockwork mafic complex where large planar veins act as crack attractors and encourage crack propagation, two breccia units where the clasts act as crack arresters and suspend crack propagation, and a dacite unit with few veins that behaves similarly to homogeneous rockmasses. This tool can be used to improve ground support design and excavation construction practices in these rockmasses. The general form of predictive brittle overbreak function for heterogeneous rockmasses by Day (2019) provides a framework to expand this tool for any heterogeneous rockmass with additional field data of overbreak observations and laboratory test data of crack initiation or unconfined compressive peak strength. In the context of a cave mining project with many planned excavations and orebody fragmentation, this overbreak prediction tool is applicable to the early stages of infrastructure development where each excavation is sufficiently distant from others that they are isolated from induced stresses caused by other excavations.

The Legacy skarn deposit case study of mineralogy and UCS tests demonstrates examples where calcite veins (where calcite is typically considered to be a weak mineral with a Mohs' hardness of 3) can strengthen or weaken a rock, depending on the wall rock mineralogy. In this case, the two tested wall rocks were calcareous mudstone and a hydrothermally altered granodiorite, respectively. Another key observation from this case study is that quartz veins (where quartz is typically considered to be a strong mineral with a Mohs' hardness of 7) in the Grt-Px skarn unit can either weaken or strengthen the rock, depending on the vein orientation and vein density. For more details on the geomechanics and mineralogy study of the Legacy skarn deposit, see Clark (2020).

Field estimation methods of vein geomechanical properties (e.g. shear strength) is an area of open research that warrants detailed study. Such methods would provide preliminary data for numerical models with discrete rockmass structures at project stages where laboratory data from direct shear or triaxial tests is unavailable.

\section{Acknowledgements}

We gratefully acknowledge financial support from the Natural Sciences and Engineering Council of Canada (NSERC), the University of New Brunswick, and Queen's University, as well as technical support from the Government of New Brunswick, Glencore Canada Corp., Osisko Metals Inc., Antofagasta Minerals S.A., and the El Teniente Division of Codelco. 


\section{References}

Allcock, JB 1982, 'Skarn and porphyry copper mineralization at Mines Gaspé, Murdochville, Quebec', Economic Geology, vol. 77, pp. 971-999.

Bahrani, N, Kaiser, PK \& Corkum, A 2018, 'Suggested methods for estimation of confined strength of heterogeneous (defected) rocks', in Proceedings of Caving 2018 Conference, eds. Y. Potvin \& J Jakubec, Australian Centre for Geomechanics, Vancouver, Canada, pp. 207-222.

Barton, NR \& Choubey, V 1977, 'The shear strength of rock joints in theory and practice', Rock Mechanics, vol. 10, pp. 1-54.

Barton, NR, Lien, R \& Lunde, J 1974, 'Engineering classification of rock masses for the design of tunnel support', Rock Mechanics, vol. 6, no. 4, pp. 189-236.

Bewick, RP, Kaiser, PK \& Amann, F 2019, 'Strength of massive to moderately jointed hard rock masses', Journal of Rock Mechanics and Geotechnical Engineering, vol. 11, pp. 562-575, https://doi.org/10.1016/j.jrmge.2018.10.003.

Bewick, RP \& Kaiser, PK 2016, 'Characterisation and classification of veined rocks for rock mass behaviour assessment', in C Carr \& G Chitombo (eds), Proceedings of MassMin 2016, Sydney, Australia, pp. 825-834.

Bewick, RP, Amann, F, Kaiser, PK \& Martin, CD 2015, 'Interpretation of UCS test results for engineering design', in Proceedings of the 13th International Congress on Rock Mechanics: ISRM Congress 2015 - Advances in Applied and Theoretical Rock Mechanics, Montreal, Canada, pp. 14.

Brzovic, A \& Molina, IL 2017, 'Integrated photogrammetry and discrete fracture network modelling to determine rock structure around excavations at the El Teniente mine', in Proceedings of 9th International Symposium on Rockbursts and Seismicity in Mines (RaSim9), Santiago, Chile, pp. 11.

Brzovic, A \& Villaescusa, E 2007, 'Rock mass characterization and assessment of block-forming geological discontinuities during caving of primary copper ore at the El Teniente mine, Chile', International Journal of Rock Mechanics and Mining Sciences, vol. 44, pp. 565-583, https://doi.org/10.1016/j.ijrmms.2006.09.010.

Bustos, N, Van Sint Jan, M, Seguel, J \& Cavieres, P 2019, 'Factors to analyse strength of mineral infilled rock mass discontinuities', Journal of Mining Engineering and Research, vol. 2, no. 2, pp. 166-174, doi:10.35624/ jminer2019.01.15.

Chitombo, GP 2010, 'Cave mining: 16 years after Laubscher's 1994 paper 'Cave mining - state of the art", Special Issue: Block and Sublevel Caving, Mining Technology, vol. 119, no. 3, pp. 132-141.

Clark, MD 2020, 'Geomechanics and mineralogical characterization of intact heterogeneous rocks from the Legacy skarn deposit', MASc Thesis, Department of Geological Sciences and Geological Engineering, Queen's University, Kingston, Canada, pp. 261.

Day, JJ 2019, 'Brittle overbreak prediction in deep excavations for hydrothermally altered and heterogeneous rockmasses', Bulletin of Engineering Geology and the Environment, vol. 79, pp. 1041-1060(2020), https://doi.org/10.1007/s10064019-01578-z.

Day, JJ, Diederichs, MS \& Hutchinson, DJ 2019, 'Composite Geological Strength Index approach with application to hydrothermal vein networks and other intrablock structures in complex rockmasses', Geotechnical and Geological Engineering, vol. 37, pp. 5285-5314(2019), https://doi.org/10.1007/s10706-019-00980-4.

Day, JJ, Diederichs, MS \& Hutchinson, DJ 2017, 'New direct shear testing protocols and analyses for fractures and healed intrablock rockmass discontinuities', Engineering Geology, vol. 229, pp. 53-72, http://dx.doi.org/10.1016/j.enggeo.2017.08.027.

Day, JJ, Diederichs, MS \& Hutchinson, DJ 2015a, 'Optimization of structural contact stiffness and strength for discrete simulation of progressive failure of healed structure', Geomechanics and Tunnelling, vol. 8, no. 5, pp. 414-420, doi: 10.1002/ geot.201500027.

Day, JJ, Diederichs, MS \& Hutchinson, DJ 2015b, 'Common core: Core logging procedures for characterization of complex rockmasses as input into geomechanical analysis for tunnel design', Tunnels and Tunnelling, vol. 1, pp. 26-32.

de los Santos, C \& Brzovic, A 2013, 'Geotechnical properties on cemented and healed stockwork veins at the El Teniente mine, Chile', in Proceedings of GEOMIN2013, 3rd International Seminar on Geology for the Mining Industry, pp. 8.

de los Santos Valderrama, CG 2011, 'Effecto de la mineralogía, alteratión, y geometría en la resistencia mecánica de las vetillas, mina El Teniente, región del libertador Bernardo O'Higgins, Chile', BSc Thesis, Departamento Ciencias de la Tierra, Facultad de Ciencias Químicas, Universidad de Concepción, in Spanish. 
Diederichs, MS 2010, 'Keynote paper: brittle spalling—practical limits', in Proceedings of BEFO2010, Swedish National Rock Mechanics Conference, Stockholm, Sweden, pp. 20.

Diederichs, MS 2007, 'The 2003 Canadian Geotechnical Colloquium: Mechanistic interpretation and practical application of damage and spalling prediction criteria for deep tunnelling', Canadian Geotechnical Journal, no. 44, pp. 1082-1116, https://doi.org/10.1139/T07-033.

Diederichs, MS 2003, 'Rock fracture and collapse under low confinement conditions', Rock Mechanics and Rock Engineering, vol. 36 , no. 5, pp. 339-381.

Everall, TJ \& Sanislav, IV 2018, 'The influence of pre-existing deformation and alteration textures on rock strength, failure modes and shear strength parameters', Geosciences, vol. 8, no 124, pp. 23, https://doi.org/10.3390/geosciences8040124.

Garza-Cruz, TV \& Pierce, ME 2016, 'Impact of rock mass strength variability on caving', in C Carr \& G Chitombo (eds), Proceedings of MassMin 2016, Sydney, Australia, pp. 359-368.

Ghazvinian, E 2015, 'Fracture initiation and propagation in low porosity crystalline rocks: implications for excavation damage zone (EDZ) mechanics', PhD Thesis, Queen's University, Kingston, Canada.

Hajiabdolmajid, V, Kaiser, PK \& Martin, CD 2002, 'Modelling brittle failure of rock', International Journal of Rock Mechanics and Mining Sciences, vol. 39, pp. 731-741, https://doi.org/10.1016/S1365-1609(02)00051-5.

Hoek, E, Carter, TG \& Diederichs, MS 2013, 'Quantification of the Geological Strength Index Chart', in Proceedings of the 47th US Rock Mechanics / Geomechanics Symposium, American Rock Mechanics Association, San Francisco, CA, USA, pp. 8.

Hoek, E, Carranza-Torres, C \& Corkum, B 2002, 'Hoek-Brown criterion-2002 Edition', in Proceedings of NARMS-TAC Conference, vol. 1, pp. 267-273.

International Centre for Diffraction Data (ICDD) 2020, 'Powder Diffraction File databases', http://www.icdd.com/.

Jacobsson, L, Flansbjer, M, Brzovic, A \& de los Santos, C 2012, 'Direct shear and tensile test on cemented healed joints from El Teniente mine, Chile', in Proceedings of the 12th International Congress of Rock Mechanics, eds. Qian \& Zhou, ISRM, Beijing, China, pp. 6.

Laubscher, DH \& Jakubec, J 2000, 'The MRMR rock mass classification for jointed rock masses', in Underground Mining Methods: Engineering Fundamentals and International Case Studies, SMME, pp. 475-481.

MacDonald, GD \& Arnold, LC 1994, 'Geological and geochemical zoning of the Grasberg Igneous Complex, Irian Jaya, Indonesia', Journal of Geochemical Exploration, vol. 50, pp. 143-178.

Martin, CD, Kaiser PK \& McCreath, DR 1999, 'Hoek-Brown parameters for predicting the depth of brittle failure around tunnels', Canadian Geotechnical Journal, vol. 36, pp. 136-151, https://doi.org/10.1139/t98-072.

Masterman, GJ, Cooke, DR, Berry, RF, Clark, AH, Archibald, DA, Mathur, R, Walshe, JL \& Durán, M 2004, '40Ar/39Ar and ReOs geochronology of porphyry copper-molybdenum deposits and related copper-silver veins in the Collahuasi District, northern Chile', Economic Geology, vol. 99, pp. 673-690, https://doi.org/10.2113/gsecongeo.99.4.673.

Ministry of Labour (MOL) 2015, 'Mining health, safety and prevention review: final report', vol. 2, add. Government of Ontario, Canada, Ministry of Labour, pp. 43.

Murphy, T, Webster, A \& Chitombo, G 2016, 'Beyond rock mass characterisation: The impact of geology on block-cave mining', in C Carr \& G Chitombo (eds), Proceedings of MassMin 2016, Sydney, Australia, pp. 861-871.

Perras, M \& Diederichs, MS 2016, 'Predicting excavation damage zone depths in brittle rocks', Journal of Rock Mechanics and Geotechnical Engineering, vol. 8, no. 1, pp. 60-74, https://doi.org/10.1016/j.jrmge.2015.11.004.

Porter, TM 2016, 'The geology, structure and mineralisation of the Oyu Tolgoi porphyry copper-gold-molybdenum deposits, Mongolia: A review', Geoscience Frontiers, vol. 7, pp. 375-407, http://dx.doi.org/10.1016/j.gsf.2015.08.003.

Shang, J 2020, 'Rupture of veined granite in polyaxial compression: insights from three-dimensional discrete element method modeling', Journal of Geophysical Research: Solid Earth, vol. 125, no. 2, pp. 25, https://doi.org/10.1029/2019JB019052.

Shang, J, Hencher, SR \& West, LJ 2016, 'Tensile strength of geological discontinuities including incipient bedding, rock joints and mineral veins', Rock Mechanics and Rock Engineering, vol. 49, pp. 4213-4225, https://doi.org/10.1007/s00603016-1041-x. 
Skewes, MA, Arévalo, A, Floody, R, Zuñiga, PH \& Stern, CR 2002, 'The giant El Teniente breccia deposit: Hypogene copper distribution and emplacement', in Integrated methods for discovery: global expansion in the twenty-first century, eds. R.J. Goldfarb \& R.L. Nielsen, Society of Economic Geologists, Special Publication 9, Paper 14, pp. 299-332.

Stavrou, A, Vazaios, I, Murphy, W \& Vlachopoulos, N 2019, 'Refined approaches for estimating the strength of rock blocks', Geotechnical and Geological Engineering, vol. 37, pp. 5409-5439, https://doi.org/10.1007/s10706-019-00989-9.

Turichshev, A \& Hadjigeorgiou, J 2017, 'Quantifying the effects of vein mineralogy, thickness, and orientation on the strength of intact veined rock', Engineering Geology, vol. 226, pp. 199-207, https://doi.org/10.1016/j.enggeo.2017.06.009.

Turichshev, A \& Hadjigeorgiou, J 2016, 'Triaxial compression experiments on intact veined andesite', International Journal of Rock Mechanics and Mining Sciences, vol. 86, pp. 179-193.

Vallejos, JA, Suzuki, K, Brzovic, A \& Mas Ivars, D 2016, 'Application of Synthetic Rock Mass modeling to veined core-size samples', International Journal of Rock Mechanics \& Mining Sciences, vol. 81, pp. 47-61, https://doi.org/10.1016/j. ijrmms.2015.11.003.

Véliz, H, Campos, E, Menzies, A \& Valdivia, L 2017, 'Relationship between hydrothermal alteration index and geological attributes at Chuquicamata Cu-Mo porphyry deposit, Chile', Resource Geology, vol. 67, no. 2, pp. 158-173, doi: 10.1111/rge.12128.

Wagner, H 2019, 'Deep mining: a rock engineering challenge', Rock Mechanics and Rock Engineering, vol. 52, pp. 1417-1446, https://doi.org/10.1007/s00603-019-01799-4. 